\title{
Antimicrobial Activities and Time-Kill Kinetics of Extracts of Selected Ghanaian Mushrooms
}

\author{
Theresa Appiah, Yaw Duah Boakye, and Christian Agyare \\ Microbiology Section, Department of Pharmaceutics, Faculty of Pharmacy and Pharmaceutical Sciences, \\ Kwame Nkrumah University of Science and Technology, Kumasi, Ghana \\ Correspondence should be addressed to Christian Agyare; chrisagyare@yahoo.com
}

Received 21 July 2017; Accepted 28 September 2017; Published 29 October 2017

Academic Editor: Letizia Angiolella

Copyright (C) 2017 Theresa Appiah et al. This is an open access article distributed under the Creative Commons Attribution License, which permits unrestricted use, distribution, and reproduction in any medium, provided the original work is properly cited.

\begin{abstract}
The rapid rise of antimicrobial resistance is a worldwide problem. This has necessitated the need to search for new antimicrobial agents. Mushrooms are rich sources of potential antimicrobial agents. This study investigated the antimicrobial properties of methanol extracts of Trametes gibbosa, Trametes elegans, Schizophyllum commune, and Volvariella volvacea. Agar well diffusion, broth microdilution, and time-kill kinetic assays were used to determine the antimicrobial activity of the extracts against selected test organisms. Preliminary mycochemical screening revealed the presence of tannins, flavonoids, triterpenoids, anthraquinones, and alkaloids in the extracts. Methanol extracts of T. gibbosa, T. elegans, S. commune, and V. volvacea showed mean zone of growth inhibition of $10.00 \pm 0.0$ to $21.50 \pm 0.84,10.00 \pm 0.0$ to $22.00 \pm 1.10,9.00 \pm 0.63$ to $21.83 \pm 1.17$, and $12.00 \pm 0.0$ to $21.17 \pm 1.00 \mathrm{~mm}$, respectively. The minimum inhibitory concentration of methanol extracts of T. gibbosa, T. elegans, S. commune, and V. volvacea ranged from 4.0 to $20,6.0$ to $30.0,8.0$ to 10.0 , and 6.0 to $20.0 \mathrm{mg} / \mathrm{mL}$, respectively. Time-kill kinetics studies showed that the extracts possess bacteriostatic action. Methanol extracts of T. gibbosa, T. elegans, S. commune, and V. volvacea exhibited antimicrobial activity and may contain bioactive compounds which may serve as potential antibacterial and antifungal agents.
\end{abstract}

\section{Introduction}

Infectious diseases pose serious threats to the existence, health, and survival of mankind [1]. The World Health Organization (WHO) survey in 2008 indicated that infectious diseases caused $32 \%$ of deaths worldwide with $68 \%$ of the deaths occurring in Africa [2]. Infectious diseases still account for a great proportion of death globally and in some regions remain the most important cause of ill health [2]. Apart from affecting the health of individuals directly, infectious diseases have heavy impact on whole societies and economies [3]. The discovery of penicillin and subsequent development and synthesis of other antibiotics had been a milestone in the history of medicine. However, this medical breakthrough is being lost to the development and rapid spread of bacterial resistance to antimicrobial agents [4].

Globally, the emergence of antimicrobial resistant bacterial strains [5] is increasingly limiting the potency of current drugs and significantly causing failure of treating infections [6]. This situation shows that the potencies of prevalent antibiotics are decreasing steadily [7]. Therefore, there is a great need to develop novel drugs to combat pathogenic microorganisms that have developed widespread microbial resistance to antibiotics [8]. Since multidrug resistance of microorganisms is a major medical concern, screening of natural products in search for new antimicrobial agents is the need of the hour [9]. The use of natural products has been extremely successful in the discovery of new medicine, and mushrooms could be a source of natural antimicrobials [10].

Reports indicate that mushrooms contain many biologically active components that offer health benefits and protection against diseases [11] and are responsible for their antitumor [12], anti-inflammatory [13], antioxidant [14], and antimicrobial activities [15]. Mushrooms have been reported in several studies to be one of the most promising sources for obtaining natural compounds that can act as anti-infective agents. Some mushrooms, including Pleurotus ostreatus [16, 17], Ganoderma lucidum [18], Russula delica [19], Phellinus hartigii [20], and Stereum ostrea [21], have been reported to exhibit wide range of antimicrobial activity against different Gram-positive, Gram-negative bacteria, and also fungi. However, the antimicrobial properties of some mushrooms have 
not been studied, while others have limited data as far as their antimicrobial activity is concerned. This has necessitated the need for the continuous screening of mushrooms for their antimicrobial activities.

Trametes gibbosa (Pers.) Fr., Trametes elegans (Spreng. Fr.) Fr., Schizophyllum commune Fr., and Volvariella volvacea are mushrooms belonging to the phylum Basidiomycota that are commonly found growing in Ghana. T. elegans is commonly known for its ability to degrade lignin [22]. However, its antibacterial and antioxidant activities have been reported $[14,23]$. T. gibbosa has been found to exhibit antibacterial [24], antioxidant [25], and cytotoxic activity [26]. Mbayo et al. [27] reported that methanol extract of T. gibbosa exhibited activity against Pseudomonas aeruginosa, Staphylococcus aureus, Streptococcus pneumoniae, and Shigella sonnei, with MIC values of $1.25,2.5,5$, and $2.5 \mathrm{mg} / \mathrm{mL}$, respectively. $S$. commune has long been acknowledged for its medical importance and have been reported to exhibit antioxidant [28], antitumor and immune-modulating [29], anti-inflammatory $[30,31]$, and antimicrobial [32] activities. Acetone and ethyl alcohol extracts of $S$. commune Fr. have been reported to exhibit activities against Escherichia coli ATCC 25922, Staphylococcus aureus, and Pseudomonas aeruginosa ATCC 27857 via the agar diffusion method [33]. $V$. volvacea is an edible mushroom that has been reported to exhibit antioxidant $[31,34]$, hepatoprotective [35], anticancer [36, 37], immunemodulatory [38], and antimicrobial [39, 40] activities. $V$. volvacea is reported to exhibit activity against Bacillus subtilis, Proteus vulgaris, and Candida albicans [41]. Ayodele and Idoko [42] reported that pure culture of $V$. volvacea collected from the grass land area of Kogi State, Nigeria, showed activity against $E$. coli and $S$. aureus. However, studies on the antimicrobial properties of mushrooms in Ghana are very limited. This study therefore investigated four Ghanaians mushrooms including fruiting bodies of Trametes gibbosa (Pers.) Fr., Trametes elegans (Spreng. Fr.) Fr., Schizophyllum commune Fr., and Volvariella volvacea for their antimicrobial properties.

\section{Materials and Methods}

2.1. Collection of Mushroom Samples. Fruiting bodies of $T$. gibbosa, T. elegans, S. commune, and V. volvacea were collected from farms and forests in Ayeduase (latitude $6^{\circ} 40^{\prime} 33 \mathrm{~N}$, longitude $1^{\circ} 33^{\prime} 36 \mathrm{~W}$, and altitude $252 \mathrm{~m}$ ) in the Ashanti Region, Ghana, from June to November 2012, from their natural habitats. These mushrooms were authenticated by $\mathrm{Mr}$. A. K. Apetorgbor, a mycologist in the Department of Theoretical and Applied Biology, Kwame Nkrumah University of Science and Technology (KNUST), Kumasi, Ghana, and voucher specimens (KNUST/HMI/2014/S005, KNUST/ HMI/ 2014/S006, KNUST/HMI/2014/S007, and KNUST/ HMI/2014/S009, resp.) deposited in the Herbarium of Department of Pharmacognosy, KNUST, Kumasi, Ghana.

2.2. Preparation of Methanol Extracts. The fruit bodies of the mushrooms were dried in an oven (Gallenkamp, London, $\mathrm{UK})$ at $30^{\circ} \mathrm{C}$ for two hours to a constant weight. The various mushroom samples were ground to fine powder using a lab mill machine (Christy and Norris, Chelmsford, UK). Two hundred grams of each sample was weighed and successively extracted with $1 \mathrm{~L}$ each of $70 \% \mathrm{v} / \mathrm{v}$ methanol. The mixture was allowed to stand at room temperature $\left(28\right.$ to $\left.30^{\circ} \mathrm{C}\right)$ for three days with frequent agitation and homogenized and the supernatant was filtered using Whatman filter paper (number 10) (Sigma-Aldrich, Michigan, USA). The filtrates were concentrated in a rotary evaporator (Rotavapor BÜCHI R200 with heating bath B-490, Büchi, Konstanz, Germany) at $40^{\circ} \mathrm{C}$ under reduced pressure and lyophilized. The yield of the extract, related to the dried powdered mushroom materials of T. gibbosa, T. elegans, S. commune, and V. volvacea, was 28, 25,20 , and $13 \% \mathrm{w} / \mathrm{w}$, respectively. The extracts were kept in air tight containers, labelled, and stored in a desiccator until required for use.

2.3. Mycochemical Screening. The methanol extracts of $T$. gibbosa, T. elegans, S. commune, and $V$. volvacea were screened to detect the presence or otherwise of secondary metabolites such as tannins, flavonoids, triterpenoids, and alkaloids, following standard procedures $[43,44]$.

2.4. Thin-Layer Chromatography (TLC) of Methanol Extracts. The methanol extracts of $V$. volvacea, T. gibbosa, T. elegans, and $S$. commune were investigated using TLC described by Marica et al. [45]. Three hundred milligrams (300 mg) of each extract was dissolved in $2 \mathrm{~mL}$ chloroform in a beaker and applied as spots with the aid of capillary tubes on a silicagel coated plate (Qingdao Marine Chemical Plant, Qingdao, China) about $1 \mathrm{~cm}$ from the base. The spotted plates were run in a developed solvent system of $100 \%$ chloroform. The developed plate was observed under ultra-violet light using both short and long wavelengths (254 and $365 \mathrm{~nm}$ ) and then sprayed with anisaldehyde (Sigma-Aldrich, London, UK) in order to reveal compounds present in the extracts. Distances between the spots were measured and the retention factor $\left(R_{f}\right)$ values were calculated, using the following:

$$
R_{f} \text { value }=\frac{\text { Distance moved by the compound }}{\text { Distance moved by the solvent front }} \text {. }
$$

2.5. Culture Media and Reference Antibiotics. Sabouraud dextrose agar, nutrient agar, and broth were purchased from Oxoid Limited, Basingstoke, UK. Ciprofloxacin (98\% HPLC) and ketoconazole (98\% HPLC) were procured from SigmaAldrich, Michigan, USA.

2.6. Test Organisms. Pure culture of Escherichia coli ATCC 25922, Pseudomonas aeruginosa ATCC 4853, Klebsiella pneumoniae ATCC 33495, Salmonella typhi ATCC 19430, Streptococcus pyogenes ATCC 19615 Staphylococcus aureus ATCC 25923, Enterococcus faecalis ATCC 29212, Bacillus subtilis NTCC 4853, and Candida albicans ATCC 10231 were obtained from the Microbiology Section, Department of Pharmaceutics, Faculty of Pharmacy and Pharmaceutical Sciences, Kwame Nkrumah University of Science and Technology (KNUST), Kumasi, Ghana. Pure cultures of Aspergillus niger, Aspergillus flavus, and Aspergillus tamarii 
were obtained from Department of Animal and Crop Science, Faculty of Agriculture, Kwame Nkrumah University of Science and Technology (KNUST), Kumasi, Ghana.

\subsection{Determination of Antimicrobial Activity Using the Agar} Well Diffusion Method. The antimicrobial activity was evaluated using the agar well diffusion method described by Agyare et al. [46]. Twenty millilitres of sterile nutrient agar and potato dextrose agar stabilized at $45^{\circ} \mathrm{C}$ for 15 minutes were seeded with $100 \mu \mathrm{L}$ of $1 \times 10^{6}$ colony forming units $(\mathrm{CFU}) / \mathrm{mL}$ of test bacteria and fungus, respectively, and aseptically poured into a sterile Petri dish and allowed to set. Four wells $(8 \mathrm{~mm})$ equidistant from each other were created with a sterile cork borer (number 4 ). The wells were filled with $200 \mu \mathrm{L}$ of $7.5,10,20$, and $30 \mathrm{mg} / \mathrm{mL}$ of methanol extracts of the mushrooms dissolved in sterile distilled water. The plate was made to stand on the bench for 30 minutes to $1 \mathrm{~h}$ to allow diffusion of the extract. The zones of growth inhibition (including diameter of well) were measured after $24 \mathrm{~h}$ of incubation at $37^{\circ} \mathrm{C}$ for bacteria and $72 \mathrm{~h}$ after incubation at $28^{\circ} \mathrm{C}$ for the fungus. Ciprofloxacin and ketoconazole (Sigma-Aldrich, Michigan, USA) were used as reference antimicrobial agents against test bacteria and fungus, respectively. The procedure was performed in independent triplicates and the mean zones of growth inhibition were determined.

2.8. Determination of Minimum Inhibitory Concentration (MIC). The minimum inhibitory concentrations (MICs) of methanol extracts of T. gibbosa, T. elegans, S. commune, and $V$ volvacea against the test organisms were determined using the broth microdilution method described by Agyare et al. [46]. Each well of a 96-well microtiter plate was filled with $100 \mu \mathrm{L}$ double strength nutrient broth. Stock solutions of extracts within the range of 0.25 to $50 \mathrm{mg} / \mathrm{mL}$ were prepared and $20 \mu \mathrm{L}$ of inoculum $\left(1 \times 10^{6} \mathrm{CFU} / \mathrm{mL}\right)$ was added to each well. The plate was incubated at $37^{\circ} \mathrm{C}$ for $24 \mathrm{~h}$. After incubation, $20 \mu \mathrm{L}$ of 3-(4,5-dimethylthiazol-2-yl)2,5-diphenyltetrazolium bromide (MTT) $(1.25 \mathrm{mg} / \mathrm{mL})$ was added to each well. The plate was incubated again at $37^{\circ} \mathrm{C}$ and growth was observed as purple coloration, while clear/yellow coloration indicated no growth after $30 \mathrm{~min}$ of incubation. The MIC was determined as the lowest concentration which showed no visible growth upon the addition of MTT. Ketoconazole at concentration ranging from 1.0 to $10.0 \mu \mathrm{g} / \mathrm{mL}$ and ciprofloxacin at concentration range of 0.01 to $1.0 \mu \mathrm{g} / \mathrm{mL}$ were used as reference standards. The procedure was performed in independent triplicates to validate the results.

2.9. Determination of Minimum Bactericidal and Fungicidal Concentrations. The minimum bactericidal concentration (MBC) and minimum fungicidal concentration (MFC) of methanol extracts of T. gibbosa, T. elegans, S. commune, and $V$. volvacea against the test organisms were determined using the method described by Cos et al. [47]. Each well of a 96well microtiter plate was filled with $100 \mu \mathrm{L}$ double strength nutrient broth. A specified volume of the stock solution was added to each well to obtain a twofold serial dilution of the extract within the range of 1 to $50 \mathrm{mg} / \mathrm{mL}$. A volume of $20 \mu \mathrm{L}$ of $1.0 \times 10^{6} \mathrm{CFU} / \mathrm{mL}$ of the test organism was added to appropriately labelled wells and incubated at $37^{\circ} \mathrm{C}$. After $24 \mathrm{~h}$ after incubation, aliquots $(10 \mu \mathrm{L})$ were taken from each well and inoculated into freshly prepared $200 \mu \mathrm{L}$ nutrient broth and incubated at $37^{\circ} \mathrm{C}$ for $24 \mathrm{~h}$. Twenty microliters $(20 \mu \mathrm{L})$ of 3(4,5-dimethylthiazol-2-yl)-2,5-diphenyltetrazolium bromide (MTT) was added after incubation and growth was observed as purple coloration, while clear/yellow coloration indicated no growth. The MBC or MFC was determined as the least concentration of the extract that exhibited no bacterial/fungal growth upon the addition of $20 \mu \mathrm{L}$ of MTT $(1.25 \mathrm{mg} / \mathrm{mL})$. The procedure was carried out in independent triplicates to validate the results.

2.10. Time-Kill Kinetics Assay. Time-kill kinetics of methanol extracts of T. gibbosa, T. elegans, S. commune, and V. volvacea was carried out following the procedure described by Tsuji et al. [48]. Concentrations equal to MIC, twice the MIC, and four times the MIC of the extracts were prepared. An inoculum size of $1.0 \times 10^{6} \mathrm{CFU} / \mathrm{mL}$ was added and incubated at $37^{\circ} \mathrm{C}$. Aliquots of $1.0 \mathrm{~mL}$ of the medium were taken at time intervals of $0,1,2,3,4,5,6,12$, and $24 \mathrm{~h}$, for bacteria, and $0,6,12,30,36,48,54$, and $72 \mathrm{~h}$ for fungi and inoculated aseptically into $20 \mathrm{~mL}$ nutrient agar and incubated at $37^{\circ} \mathrm{C}$ for $24 \mathrm{~h}$. A control test was performed for the organisms without the extracts or reference antibiotic. The colony forming unit (CFU) of the organisms was determined. The procedure was performed in triplicate (three independent experiments) and a graph of the $\log \mathrm{CFU} / \mathrm{mL}$ was plotted against time.

2.11. Statistical Analysis. Graph Pad Prism Version 7.0 for Windows (Graph Pad Software Inc., San Diego, CA, USA) was used to analyze data obtained from study by using oneway ANOVA followed by Dunnett's post hoc test.

\section{Results}

3.1. Mycochemical Analysis. The methanol extracts of $T$. gibbosa, T. elegans, S. commune, and $V$. volvacea were found to contain secondary metabolites such as tannins, flavonoids, triterpenoids, glycosides, and alkaloids. However, coumarins were absent in all four mushroom extracts, and anthraquinones were present in T. gibbosa, T. elegans, and $S$. commune but absent in $V$. volvacea, while saponins were absent in T. gibbosa, T. elegans, and $S$. commune but present in $V$. volvacea (Table 1).

3.2. TLC of Methanol Extracts. The $R_{f}$ values of the identified bands that eluted from T. gibbosa, T. elegans, S. commune, and $V$. volvacea spots on the TLC plates were calculated (Figure 1). T. gibbosa, T. elegans, and S. commune extract each resulted in ten (10) bands that eluted from the spot, while seven (7) bands eluted from $V$. volvacea extract. However, all four extracts had some bands that were similar as they had the same characteristic fluorescence at both $254 \mathrm{~nm}$ and $365 \mathrm{~nm}$ (Figure 1). 
TABLE 1: Analysis of mycochemical content in extracts of T. gibbosa, T. elegans, S. commune, and V. volvacea.

\begin{tabular}{|c|c|c|c|c|}
\hline \multirow{2}{*}{ Secondary metabolite } & \multicolumn{4}{|c|}{ Mushroom samples } \\
\hline & T. gibbosa & V. volvacea & T. elegans & S. commune \\
\hline Tannins & + & + & + & + \\
\hline Flavonoids & + & + & + & + \\
\hline Triterpenoids & + & + & + & + \\
\hline Alkaloids & + & + & + & + \\
\hline Coumarins & - & - & - & - \\
\hline Glycosides & + & + & + & + \\
\hline Anthraquinones & + & - & + & + \\
\hline Saponins & - & + & - & - \\
\hline
\end{tabular}

+: presence of secondary metabolite; -: absence of secondary metabolite.

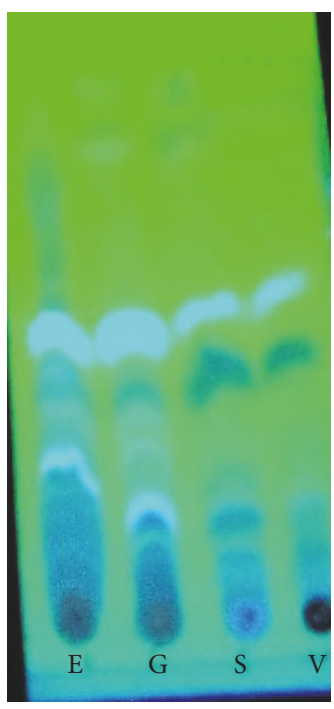

(a) $\lambda 254 \mathrm{~nm}$

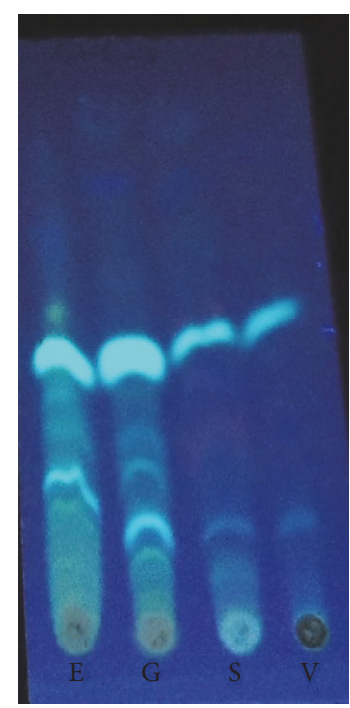

(b) $\lambda 365 \mathrm{~nm}$

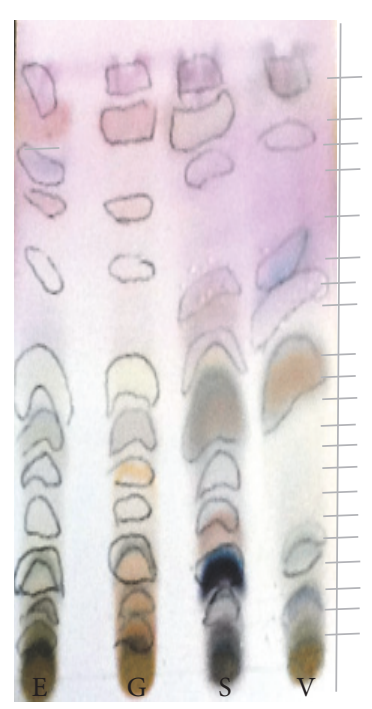

(c) Daylight

FIGURE 1: TLC of methanol extracts of mushrooms developed in 100\% chloroform. E: T. elegans; T: T. gibbosa; V: V. volvacea; S: S. commune. (a) Observed under $\lambda 254 \mathrm{~nm}$, (b) observed under $\lambda 365 \mathrm{~nm}$, and (c) daylight after spraying with anisaldehyde reagent.

\subsection{Antimicrobial Activity of Extracts}

3.3.1. Agar Well Diffusion. T. gibbosa extract at the highest concentration of $30 \mathrm{mg} / \mathrm{mL}$ showed mean zone of growth inhibition of $14.00 \pm 1.33$ to $20.50 \pm 0.55 \mathrm{~mm}$ against test Gram-positive bacteria, $20.67 \pm 0.82$ to $21.12 \pm 1.23 \mathrm{~mm}$ against Gram-negative bacteria, and $19.50 \pm 0.55 \mathrm{~mm}$ against C. albicans (Table 2). T. elegans extract at the highest concentration of $30 \mathrm{mg} / \mathrm{mL}$ showed mean zone of growth inhibition of $22.00 \pm 1.10$ to $14.33 \pm 0.82 \mathrm{~mm}, 23.50 \pm 0.55$ to $12.67 \pm$ $1.30 \mathrm{~mm}$, and $18.00 \pm 0.75 \mathrm{~mm}$ against test Gram-positive bacteria, Gram-negative bacteria, and C. albicans, respectively (Table 2). S. commune extract at the highest concentration of $30 \mathrm{mg} / \mathrm{mL}$ showed mean zone of growth inhibition of $21.83 \pm$ 1.17 to $20.50 \pm 0.55 \mathrm{~mm}$ against test Gram-positive bacteria, $21.60 \pm 0.98$ to $16.67 \pm 0.52 \mathrm{~mm}$ against test Gram-negative bacteria, and $21.67 \pm 0.52 \mathrm{~mm}$ against C. albicans (Table 3 ). $V$. volvacea extract at the highest concentration of $30 \mathrm{mg} / \mathrm{mL}$ showed mean zone of growth inhibition of $19.50 \pm 0.55$ to $16.50 \pm 0.55 \mathrm{~mm}$ against test Gram-positive bacteria and
$22.50 \pm 0.55$ to $21.17 \pm 1.00 \mathrm{~mm}$ against test Gram-negative bacteria but showed no activity against C. albicans (Table 3). However, all four mushroom extracts showed no inhibition against $A$. niger, A. flavus, and A. tamarii (Tables 2 and 3).

3.4. MIC, MBC, and MFC of Extracts. T. gibbosa and T elegans extracts had antimicrobial activity against test organisms with minimum inhibitory concentration (MIC) ranging from 4 to $20 \mathrm{mg} / \mathrm{mL}$ and 6 to $30 \mathrm{mg} / \mathrm{mL}$, respectively (Table 4 ), while $S$. commune and $V$. volvacea extracts had MIC range of 6 to $20 \mathrm{mg} / \mathrm{mL}$ each (Table 5). The MBC of extract of T. gibbosa against test Gram-negative and Gram-positive bacteria were between the ranges of 20 to $50 \mathrm{mg} / \mathrm{mL}$, while the MBC of extracts of $T$. elegans, $V$ volvacea, and $S$. commune were between the ranges of 30 to $50 \mathrm{mg} / \mathrm{mL}$ each. MFC was only available for the extracts of $T$. elegans and $S$. commune with MFCs of 30 and $50 \mathrm{mg} / \mathrm{mL}$, respectively (Tables 4 and 5).

3.5. MBC/MIC and MFC/MIC Ratios of Extracts. MBC/MIC ratios of extract of $T$. elegans against test Gram-negative 


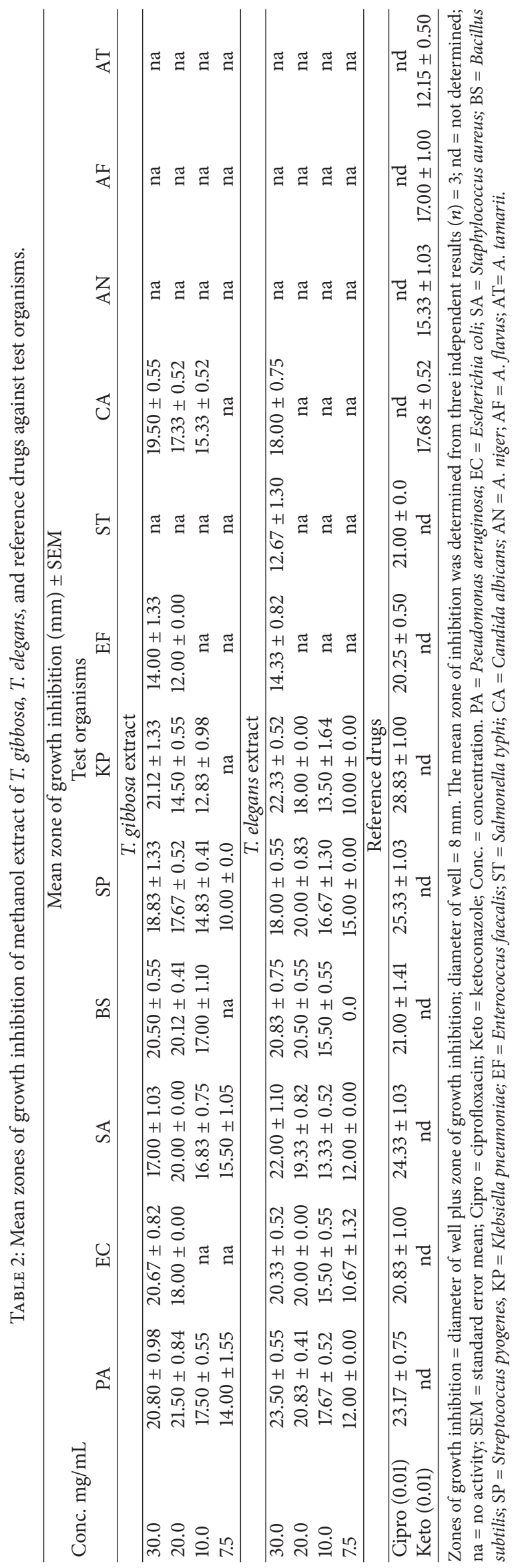




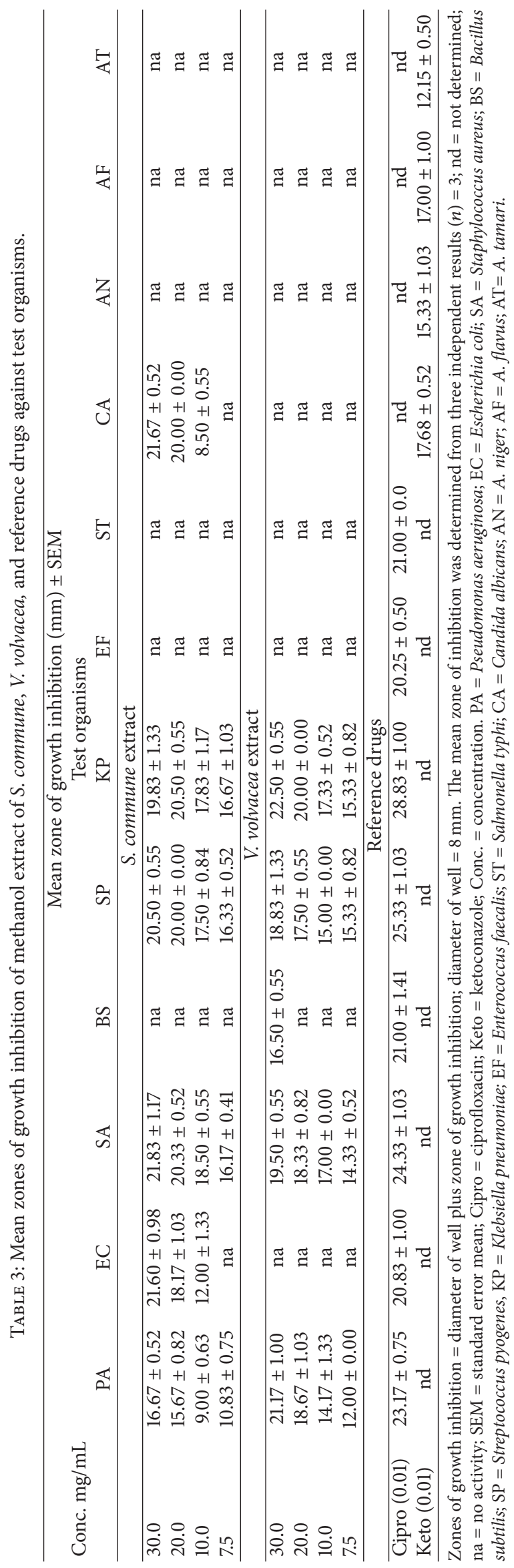


TABLE 4: MIC and MBC/MFC of crude methanol extracts of T. gibbosa, T. elegans, and reference drugs against test organisms.

\begin{tabular}{|c|c|c|c|c|c|c|}
\hline \multirow[b]{2}{*}{ Test organisms } & \multicolumn{2}{|c|}{ T. gibbosa } & \multicolumn{2}{|c|}{ T. elegans } & \multirow{2}{*}{$\begin{array}{c}\text { Cipro } \\
\text { MIC } \\
(\mu \mathrm{g} / \mathrm{mL})\end{array}$} & \multirow{2}{*}{$\begin{array}{c}\text { Keto } \\
\mathrm{MIC} \\
(\mu \mathrm{g} / \mathrm{mL})\end{array}$} \\
\hline & $\begin{array}{c}\text { MIC } \\
(\mathrm{mg} / \mathrm{mL})\end{array}$ & $\begin{array}{c}\mathrm{MBC} \\
(\mathrm{mg} / \mathrm{mL})\end{array}$ & $\begin{array}{c}\text { MIC } \\
(\mathrm{mg} / \mathrm{mL})\end{array}$ & $\begin{array}{c}\mathrm{MBC} \\
(\mathrm{mg} / \mathrm{mL})\end{array}$ & & \\
\hline E. coli & 6 & 30 & 8 & 50 & $\leq 0.16$ & nd \\
\hline P. aeruginosa & 6 & 50 & 8 & 50 & $\leq 0.31$ & nd \\
\hline S. pyogenes & 6 & 30 & 8 & 50 & $\leq 0.31$ & nd \\
\hline S. typhi & 8 & 50 & 20 & - & 2 & nd \\
\hline S. aureus & 6 & 30 & 6 & 30 & $\leq 0.31$ & nd \\
\hline K. pneumonia & 6 & 30 & 6 & 50 & 0.63 & nd \\
\hline B. subtilis & 4 & 20 & 6 & 30 & 0.16 & nd \\
\hline E. faecalis & 8 & 50 & 30 & - & 3.5 & nd \\
\hline C. albicans & 20 & - & 6 & 30 & nd & $\leq 0.31$ \\
\hline A. niger & - & - & - & - & nd & 0.35 \\
\hline A. flavus & - & - & - & - & nd & 0.50 \\
\hline A. tamarii & - & - & - & - & nd & 2.00 \\
\hline
\end{tabular}

MIC: minimum inhibitory concentration; MBC: minimum bactericidal concentration; nd $=$ not determined; $-=\mathrm{MIC} / \mathrm{MBC}$ not present $/>$ highest test concentration $(50 \mathrm{mg} / \mathrm{mL})$; Cipro = ciprofloxacin; Keto = ketoconazole.

TABLE 5: MIC and MBC/MFC of crude methanol extracts of $V$. volvacea, S. commune, and reference drugs (ciprofloxacin and ketoconazole) against test organisms.

\begin{tabular}{|c|c|c|c|c|c|c|}
\hline \multirow[b]{2}{*}{ Test organisms } & \multicolumn{2}{|c|}{$V$. volvacea } & \multicolumn{2}{|c|}{ S. commune } & \multirow{2}{*}{$\begin{array}{c}\text { Cipro } \\
\text { MIC } \\
(\mu \mathrm{g} / \mathrm{mL})\end{array}$} & \multirow{2}{*}{$\begin{array}{c}\text { Keto } \\
\text { MIC } \\
(\mu \mathrm{g} / \mathrm{mL})\end{array}$} \\
\hline & $\begin{array}{c}\mathrm{MIC} \\
(\mathrm{mg} / \mathrm{mL})\end{array}$ & $\begin{array}{c}\mathrm{MBC} \\
(\mathrm{mg} / \mathrm{mL})\end{array}$ & $\begin{array}{c}\mathrm{MIC} \\
(\mathrm{mg} / \mathrm{mL})\end{array}$ & $\begin{array}{c}\mathrm{MBC} \\
(\mathrm{mg} / \mathrm{mL})\end{array}$ & & \\
\hline P. aeruginosa & 10 & 50 & 8 & 50 & $\leq 0.31$ & nd \\
\hline S. pyogenes & 8 & 50 & 8 & 50 & $\leq 0.31$ & nd \\
\hline S. typhi & - & - & - & - & 2.00 & nd \\
\hline S. aureus & 8 & 50 & 6 & 30 & $\leq 0.31$ & nd \\
\hline K. pneumonia & 6 & 30 & 6 & 30 & 0.63 & nd \\
\hline B. subtilis & - & - & - & - & nd & nd \\
\hline E. faecalis & - & - & - & - & 3.50 & nd \\
\hline C. albicans & 20 & - & 10 & 50 & 0.16 & $\leq 0.31$ \\
\hline A. niger & - & - & - & - & nd & 0.35 \\
\hline A. flavus & - & - & - & - & nd & 0.50 \\
\hline A. tamarii & - & - & - & - & nd & 2.00 \\
\hline
\end{tabular}

MIC: minimum inhibitory concentration; MBC: minimum bactericidal concentration; nd $=$ not determined; $-=\mathrm{MIC} / \mathrm{MBC}$ not present $/>$ highest test concentration $(50 \mathrm{mg} / \mathrm{mL})$; Cipro = ciprofloxacin; Keto = ketoconazole.

and Gram-positive bacteria were between the ranges of 5 to 8 , while the MBC/MIC ratios of extracts of T. elegans, $V$. volvacea, and $S$. commune were between the ranges of 5 to 6 each. The MFC/MIC ratio was 5 each for extracts of T. gibbosa and $S$. commune against C. albicans, whereas no MFC/MIC ratio was recorded for the methanol extracts of T. elegans and V. volvacea (Table 6).

3.6. Time-Kill Kinetics of Extracts. The time-kill kinetics profile of extract of T. gibbosa against the test organisms $E$. coli, S. aureus, and C. albicans at test concentrations showed reduction in number of viable cells over the first 5,6 , and 48 hours, respectively, followed by a gradual rise up to the 24th h for E. coli and S. aureus and 72nd h for C. albicans when compared to the control (organisms without antimicrobial agent) (Figure 2). The time-kill kinetics profile of extract of T. elegans against the test organisms; E. coli, S. aureus, and C. albicans at test concentrations studied showed reduction in number of viable cells over the first 5, 6, and 52 hours, respectively, followed by a gradual rise up to the 24 th $\mathrm{h}$ for $E$. coli and $S$. aureus and 72nd h for C. albicans when compared to the control (Figure 3).

The time-kill kinetics profile of methanol extract of $S$. commune against the test organisms E. coli, S. aureus, and C. albicans at test concentrations showed reduction in number of viable cells over the first 6,4 , and 36 hours, respectively, 
TABLE 6: MBC/MIC and MFC/MIC ratios of methanol extracts of T. gibbosa, T. elegans, S. commune, and V. volvacea against test organisms.

\begin{tabular}{|c|c|c|c|c|}
\hline \multirow{2}{*}{ Test organisms } & \multicolumn{4}{|c|}{$\mathrm{MBC} / \mathrm{MIC}$ and MFC/MIC ratio } \\
\hline & T. gibbosa & T. elegans & S. commune & V. volvacea \\
\hline E. coli & 5 & 6 & 5 & na \\
\hline P. aeruginosa & 5 & 6 & 6 & 5 \\
\hline S. pyogenes & 5 & 6 & 6 & 6 \\
\hline S. typhi & 6 & na & na & na \\
\hline S. aureus & 5 & 5 & 5 & 6 \\
\hline K. pneumonia & 5 & 8 & 5 & 5 \\
\hline B. subtilis & 5 & 5 & na & na \\
\hline E. faecalis & 6 & na & na & na \\
\hline C. albicans & na & 5 & 5 & na \\
\hline A. niger & na & na & na & na \\
\hline A. flavus & na & na & na & na \\
\hline A. tamarii & na & na & na & na \\
\hline
\end{tabular}

$\mathrm{na}=\mathrm{MBC} / \mathrm{MIC}$ or MFC/MIC ratio not available.

followed by a gradual rise up to the 24th h for E. coli and $S$. aureus and $72 \mathrm{nd}$ h for C. albicans when compared to the control (Figure 4).

The time-kill kinetics profile of extract of $V$. volvacea against the test organisms; E. coli, S. aureus, and C. albicans at test concentrations showed reduction in number of viable cells over the first 6,8 , and 42 hours, respectively, followed by a gradual rise up to the 24 th h for $E$. coli and $S$. aureus and 72 nd h for $C$. albicans when compared to the control (Figure 5). The course of antimicrobial action was however observed to be bacteriostatic and concentration dependent for extracts of all four mushrooms (T. elegans, T. gibbosa, S. commune, and $V$. volvacea) studied. The area under the curve (AUC) for T. gibbosa, T. elegans, S. commune, and V. volvacea against E. coli, S. aureus, and C. albicans at concentrations studied revealed that the number of cells was significantly $(p<0.0001)$ reduced when compared to the control (Figures $2-5)$.

\section{Discussion}

Research into the pharmacological activities of mushrooms especially their antimicrobial activity has attracted attention recently. The methanol extracts of T. gibbosa, T. elegans, and $S$. commune and $V$. volvacea were found to contain secondary metabolites such as tannins, flavonoids, triterpenoids, glycosides, and alkaloids. However, the absence of anthraquinones in T. gibbosa, T. elegans, and S. commune extracts and the presence of saponins in $V$. volvacea extract (Table 1) may be due to the differences in substrates from which the various samples were collected $[49,50]$. The presence of saponins, tannins, terpenoids, flavonoids, and alkaloids in T. gibbosa is similar to the report by Mbayo et al. [27] that indicated the presence of tannins, terpenoids, anthocyanins, flavonoids, and alkaloids in T. gibbosa. The presence of phenolic compounds in T. elegans has been reported by Awala and Oyetayo [14]. The presence of flavonoid in S. commune is reported to be responsible for its antimicrobial activity [51].
TLC profile of the extracts, visualized under visible light, indicated the number of bands that eluted from the various extracts. Since silica gel retains the more polar compounds, the nonpolar compounds eluted first and moved further up the TLC plate. Hence, the more polar the compound, the lower the $R_{f}$ (Retention factor) value and the less polar the compound the larger the $R_{f}$ value. Thus, it could be said that the mushroom extracts studied have both polar and nonpolar compounds. However, all four extracts (T. gibbosa, T. elegans, $S$. commune, and $V$. volvacea) showed bands that were similar as they had the same characteristic fluorescence and $R_{f}$ value (0.89) (Figure 1). This may be due to the fact they belong to the same class, Basidiomycetes [52], and therefore may possess similar compounds or secondary metabolites.

T. gibbosa, T. elegans, and S. commune and V. volvacea have antimicrobial agents or principles present in their extracts though the extent of growth inhibition varied. The antimicrobial activity of methanol extracts of T. gibbosa, T. elegans, S. commune, and $V$. volvacea may be due to the presence of the secondary metabolites that act individually or in synergism to inhibit the growth of the test organisms [53]. The differences in the diameter zone of inhibition for $T$. gibbosa and T. elegans at the highest concentration of $30 \mathrm{~g} / \mathrm{mL}$ and the next highest concentration of $20 \mathrm{mg} / \mathrm{mL}$ (Table 2) may be as a result of the effect of diffusion of the bioactive agents within the medium [54]. Compared with the reference antibiotics, T. gibbosa had broad spectrum of activity against the test organisms. This is however in contrast to the findings of Ga and Kaviyarasana [24] who reported that methanol extract of T. gibbosa exhibited narrow antibacterial activity against S. aureus, B. subtilis, and Micrococcus flavus, but rather in agreement with the report by Mbayo et al. [27] which revealed that methanol extract of T. gibbosa exhibited broad spectrum activity against Pseudomonas aeruginosa, Staphylococcus aureus, Streptococcus pneumoniae, and Shigella sonnei.

Methanol extract of T. elegans inhibited the growth of all test bacteria (Table 2). Though reports on the antimicrobial activity of T. elegans are limited, its inhibitory activity against the test organisms could be attributed to the presence of 

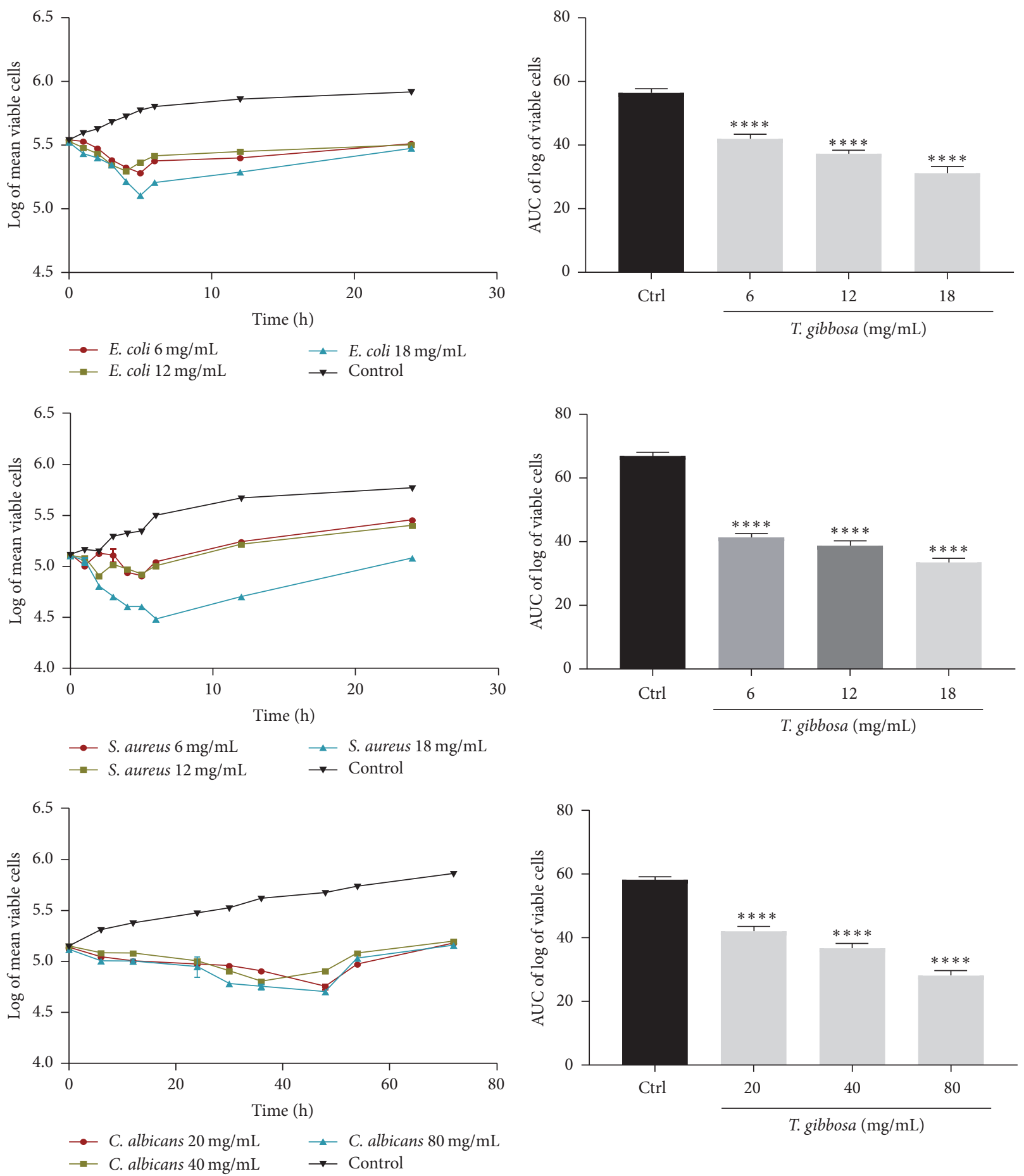

(a)

(b)

Figure 2: Time-kill kinetics of T. gibbosa methanol extract against E. coli, S. aureus, and C. albicans. (a) Time-kill kinetics curve and (b) AUC of time-kill kinetics. Ctrl: control; $n=3$; values are mean \pm SEM. ${ }^{* * * *} p<0.0001$ compared to the control (one-way ANOVA followed by Dunnett's post hoc test).

bioactive compounds and secondary metabolites such as flavonoids, tannins, and triterpenoids [55]. The inhibitory action of T. elegans is not surprising as members of the same genus have been reported to possess antimicrobial activity [56].
Microbial growth inhibition was exhibited by extract of $S$. commune against the test bacteria except $B$. subtilis. The high zone of growth inhibition exhibited by $S$. commune extract against C. albicans (Table 3 ) is in agreement with the results previously reported by Ooi and Liu [57]. The inhibition of 

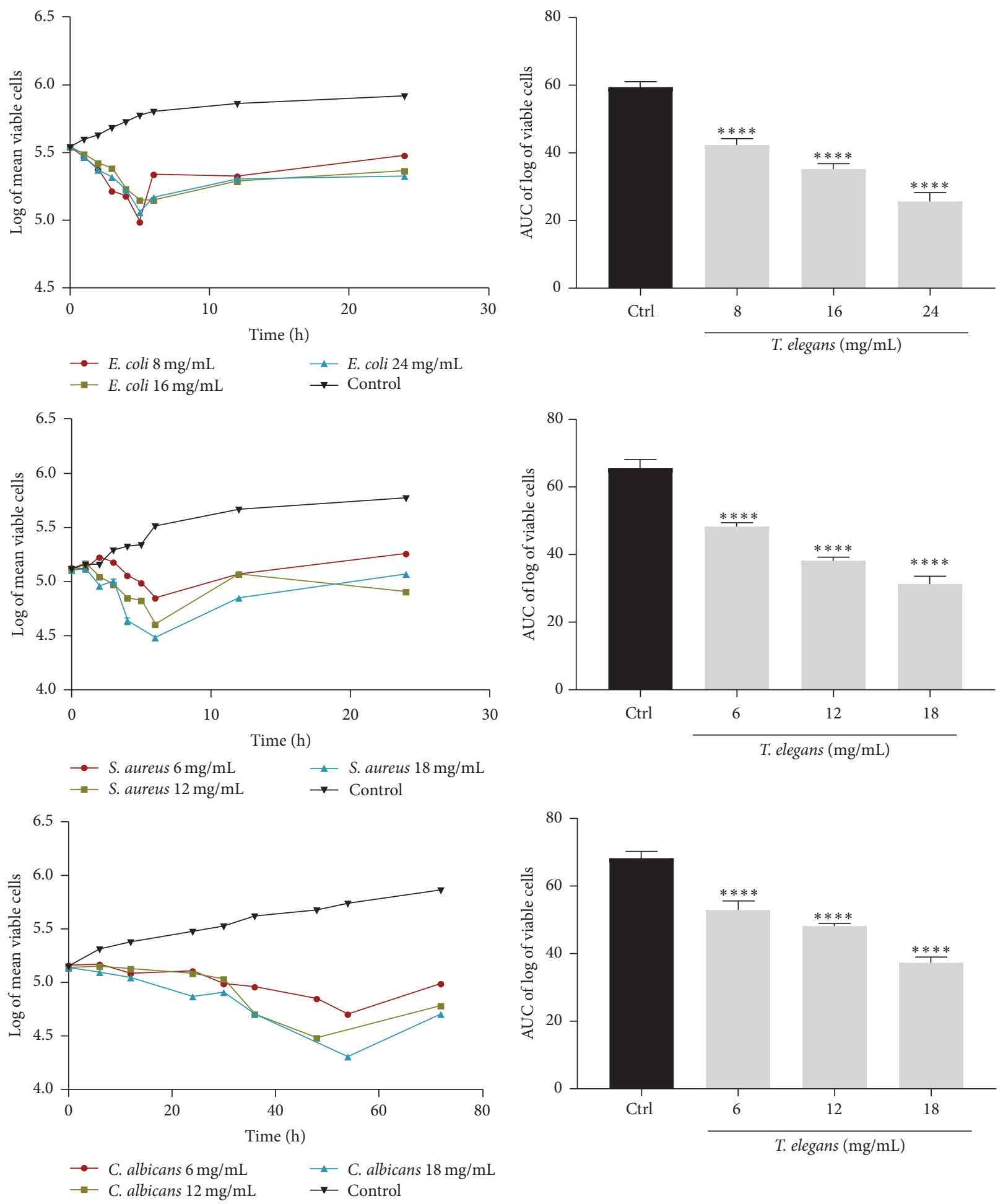

(a)

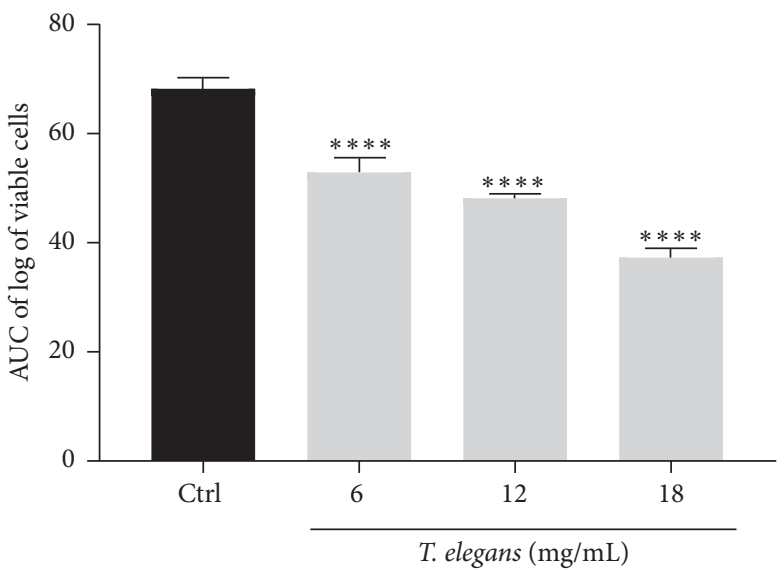

(b)

FIgURE 3: Time-kill kinetics of T. elegans methanol extract against E. coli, S. aureus, and C. albicans. (a) Time-kill kinetics curve and (b) AUC of time-kill kinetics. Ctrl: control; $n=3$; values are mean \pm SEM. ${ }^{* * * *} p<0.0001$ compared to the control (one-way ANOVA followed by Dunnett's post hoc test).

growth by extract of $S$. commune against E. coli, S. aureus, K. pneumonia, P. aeruginosa, and S. pyogenes is in agreement with the findings of Matsuyama et al. [58].
$V$. volvacea extract inhibited the growth of $S$. aureus, $K$. pneumoniae, $P$. aeruginosa, and S. pyogenes (Table 3) but showed no antimicrobial activity against $E$. coli and 

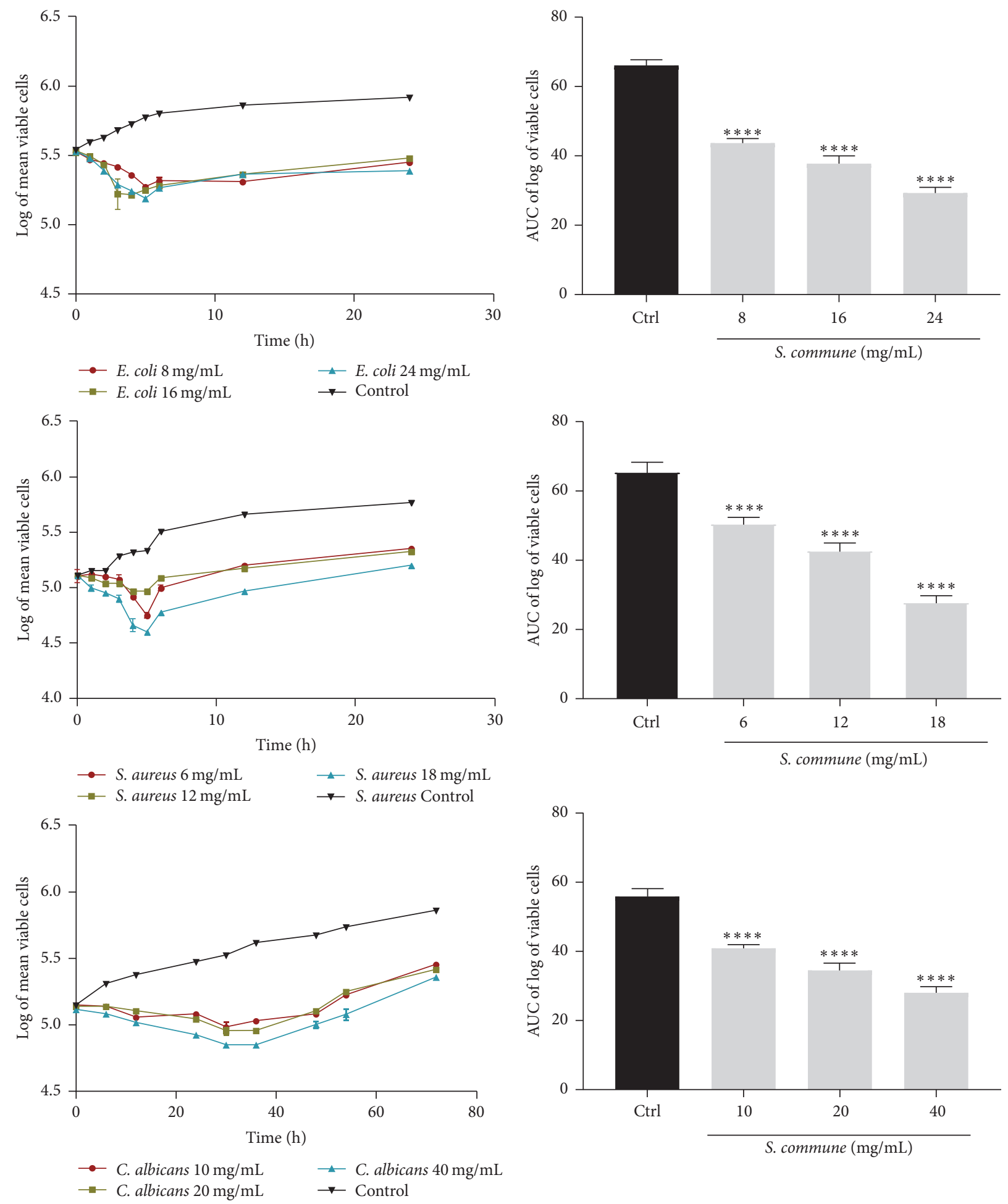

(a)

(b)

FIGURE 4: Time-kill kinetics of S. commune methanol extract against E. coli, S. aureus, and C. albicans. (a) Time-kill kinetics curve and (b) AUC of time-kill kinetics. Ctrl: control; $n=3$; values are mean \pm SEM. ${ }^{* * *} p<0.0001$ compared to the control (one-way ANOVA followed by Dunnett's post hoc test).

C. albicans and this is in agreement with the findings of da Silva et al. [40] that $V$. volvacea exhibits less significant antimicrobial activity, but it exhibited good antioxidant activity. Again, the methanol extracts of all the four mushrooms ( $V$. volvacea $T$. elegans, T. gibbosa, and $S$. commune) showed no activity against $A$. niger, A. flavus, and $A$. tamarii (Tables 2 and 3 ). This observation supports the findings of Suay et al. [59] and Papadopoulou et al. [60] who 

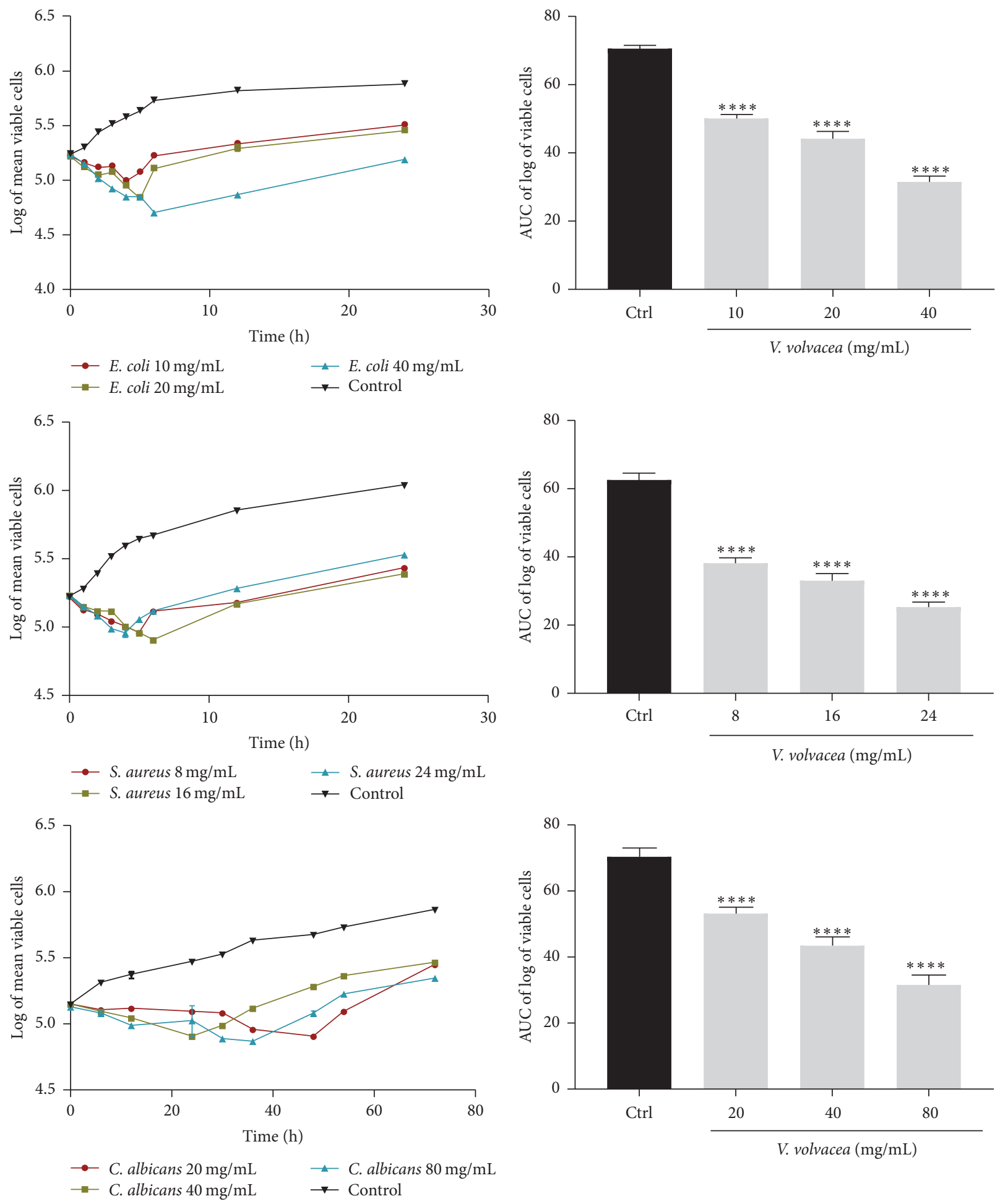

(a)

(b)

FIGURE 5: Time-kill kinetics of V. volvacea methanol extract against E. coli, S. aureus, and C. albicans. (a) Time-kill kinetics curve and (b) AUC of time-kill kinetics. Ctrl: control; $n=3$; values are mean \pm SEM. ${ }^{* * *} p<0.0001$ compared to the control (one-way ANOVA followed by Dunnett's post hoc test).

reported that polypores and gilled mushrooms are found to exhibit more pronounced antibacterial than antifungal activity.
To overcome the drawbacks of the agar diffusion test including the inability of some extracts to diffuse into agar and to distinguish bactericidal and bacteriostatic 
effects, the broth dilution method was employed to determine the potency of the extracts. From the MIC results, all four mushroom extracts inhibited the growth of Gramnegative and Gram-positive bacteria (Tables 4 and 5). The above observations support the findings of the broad spectrum antimicrobial activity of some mushrooms. For example, Pleurotus ostreatus and Meripilus giganteus have been found to exhibit broad spectrum antimicrobial activity $[61,62]$.

Antimicrobials are usually regarded as bactericidal if the $\mathrm{MBC} / \mathrm{MIC}$ or $\mathrm{MFC} / \mathrm{MIC}$ ratio is $\leq 4$ and bacteriostatic if $>4$ [63]. The ratios obtained for all the test organisms were above 4 which indicated that all four mushroom extracts were bacteriostatic and fungistatic in action against test organisms (Table 6). The bacteriostatic action of these mushroom extracts was also confirmed by the time-kill kinetic studies. Bacteriostatic or fungistatic antimicrobial agents only inhibit the growth or multiplication of pathogenic microorganisms and thus require the host immune system to aid in the elimination of the pathogen $[64,65]$.

Time-kill kinetic studies indicate that methanol extracts of T. gibbosa, T. elegans, S. commune, and V. volvacea exhibited bacteriostatic actions. There are few reports on the time-kill kinetic studies of mushrooms, and several reports of the natural product extracts have been reported $[64,66]$. However, the findings in this study are in contrast with the study of Tinrat [67] who determined the time-kill kinetic activity of the mushrooms Pleurotus sajor-caju, Hypsizygus tessellatus, Lentinus edodes, Flammulina velutipes, and Pleurotus eryngii and found them to exhibit bactericidal activity. There is the need to isolate and characterize the bioactive compounds in the various extracts responsible for the antimicrobial activity.

\section{Conclusion}

Methanol extracts of T. gibbosa, T. elegans, S. commune, and V. volvacea exhibited antimicrobial activity but were not active against $A$. niger, $A$. flavus, and A. tamarii. Methanol extracts of T. elegans and T. gibbosa exhibited static activity against $E$. coli, S. aureus, and C. albicans and hence there is a need to isolate and purify the agents or molecules from the extracts responsible for the antimicrobial properties which may serve as potential antibiotics.

\section{Conflicts of Interest}

The authors declare that there are no conflicts of interest.

\section{Acknowledgments}

The authors wish to thank the Organization for Women in Science for Developing Countries (OWSD) and the Mwalimu Nyerere African Union Scholarship for Theresa Appiah. The authors are thankful to Mr. Francis Amankwah, Microbiology Section, Department of Pharmaceutics, Kwame Nkrumah University of Science and Technology, Kumasi, Ghana, for his assistance in the laboratory work.

\section{References}

[1] M. Yamac and F. Bilgili, "Antimicrobial activities of fruit bodies and/or mycelial cultures of some mushroom isolates," Pharmaceutical Biology, vol. 44, no. 8, pp. 660-667, 2006.

[2] World Health Organization WHO, Antimicrobial Resistance Secretariat, World Health Organization, Geneva, Switzerland, 2017, http://www.who.int/mediacentre/news/releases/2017/bacteria-antibiotics-needed/en/.

[3] A. S. Fauci, N. A. Touchette, and G. K. Folkers, "Emerging infectious diseases: a 10 -year perspective from the National Institute of Allergy and Infectious Diseases," Emerging Infectious Diseases, vol. 11, no. 4, pp. 519-525, 2005.

[4] D. M. Livermore, "The need for new antibiotics," Clinical Microbiology and Infection, Supplement, vol. 10, no. 4, pp. 1-9, 2004.

[5] World Health Organization (WHO), "Human and economic burden. In working to overcome the global impact of neglected tropical diseases," First WHO Report on Neglected Tropical Diseases, WHO, Geneva, Switzerland, 2017, Doc. WHO/HTM/NTD/2010.1,13-9.

[6] R. E. W. Hancock, "Mechanisms of action of newer antibiotics for Gram-positive pathogens," The Lancet Infectious Diseases, vol. 5, no. 4, pp. 209-218, 2005.

[7] A. Shahghasi, G. H. Shahidi, M. H. Fooladi, and M. J. Mahdavi, "Broadspectrim, a novel antibacterial from Streptomyces sp," Biotechnology, vol. 3, no. 2, pp. 26-130, 2004.

[8] B. T. Gulgun, "Disruption of Bacterial cell-to-cell communication (Quorum Sensing): a promising novel way to combat bacteria-mediated diseases," Journal of Marmara University Institute of Health Sciences, vol. 3, no. 3, pp. 159-163, 2013.

[9] J. R. Zgoda and J. R. Porter, "A convenient microdilution method for screening natural products against bacteria and fungi," Pharmaceutical Biology, vol. 39, no. 3, pp. 221-225, 2001.

[10] G. Alves, J. Sallé, S. Chaudy, S. Dupas, and G. Manière, "High$\mathrm{NaCl}$ perception in Drosophila melanogaster," The Journal of Neuroscience, vol. 34, no. 33, pp. 10884-10891, 2014.

[11] L. Barros, B. A. Venturini, P. Baptista, L. M. Estevinho, and I. C. F. R. Ferreira, "Chemical composition and biological properties of Portuguese wild mushrooms: a comprehensive study," Journal of Agricultural and Food Chemistry, vol. 56, no. 10, pp. 3856-3862, 2008.

[12] Y. Zang, J. Xiong, W.-Z. Zhai et al., "Fomentarols A-D, sterols from the polypore macrofungus Fomes fomentarius," Phytochemistry, vol. 92, pp. 137-145, 2013.

[13] T. F. Liu, X. Lu, H. Tang, M. M. Zhang, P. Wang, P. Sun et al., " $3 \beta, 5 \alpha, 6 \beta$-Oxygenated sterols from the South China Sea gorgonian Muriceopsis flavida and their tumor cell growth inhibitory activity and apoptosis-inducing function," Steroids, vol. 78, no. 1, pp. 108-114, 2013.

[14] S. Awala and V. Oyetayo, "Molecular identity and antimicrobial profile of Trametes species Collected from the Teaching and Research Farm of the Federal University of Technology, Akure, Nigeria," Journal of Advances in Medical and Pharmaceutical Sciences, vol. 4, no. 3, pp. 1-14, 2015.

[15] M. J. Alves, I. C. F. R. Ferreira, H. J. C. Froufe, R. M. V. Abreu, A. Martins, and M. Pintado, "Antimicrobial activity of phenolic compounds identified in wild mushrooms, SAR analysis and docking studies," Journal of Applied Microbiology, vol. 115, no. 2, pp. 346-357, 2013.

[16] J. Cilerdzic, M. Stajic, J. Vukojevic, I. Milovanovic, and N. Muzgonja, "Antioxidant and antifungal potential of Pleurotus 
ostreatus and Agrocybe cylindracea basidiocarps and mycelia," Current Pharmaceutical Biotechnology, vol. 16, no. 2, pp. 179186, 2015.

[17] A. M. Younis, F.-S. Wu, and H. H. El Shikh, "Antimicrobial activity of extracts of the oyster culinary medicinal mushroom Pleurotus ostreatus (higher basidiomycetes) and identification of a new antimicrobial compound," International Journal of Medicinal Mushrooms, vol. 17, no. 6, pp. 579-590, 2015.

[18] A. Roy and P. Prasad, "Therapeutic potential of Pleurotus ostreatus: A review," Research Journal of Pharmacy and Technology, vol. 6, no. 9, pp. 937-940, 2013.

[19] A. Turkoglu, M. E. Duru, N. Mercan, I. Kivrak, and K. Gezer, "Antioxidant and antimicrobial activities of Laetiporus sulphureus(Bull.) Murrill," Food Chemistry, vol. 101, no. 1, pp. 267273, 2007.

[20] E. M. Altuner and I. Akata, "Antimicrobial activity of some macrofungi extracts," Antimicrobial Activity of Some Macrofungi Extracts, vol. 14, no. 1, pp. 45-49, 2010.

[21] K. Praveen, K. Y. Usha, M. Naveen, and B. R. Rajasekhar, "Antibacterial Activity of a Mushroom-Stereum ostrea," Journal of Biology and Agriclture Healthcare, vol. 2, no. 1, pp. 1-5, 2012.

[22] M. A. Lara, A. J. Rodríguez-Malaver, O. J. Rojas et al., "Black liquor lignin biodegradation by Trametes elegans," International Biodeterioration \& Biodegradation, vol. 52, no. 3, pp. 167-173, 2003.

[23] D. Aina, O. Olawuyi, G. Mensah-Agyei, A. Laiya, and M. Adeoye-Isijola, "Comparative phytochemical evaluation, antimicrobial and antioxidant properties of methanolic and ethanolic extracts of Daedalea elegans-a Nigerian Mushroom," Advance Pharmaceutical Journal, vol. 1, no. 2, pp. 38-42, 2016.

[24] J. Ga and V. Kaviyarasana, "Antimicrobial and antioxidant properties of Trametes gibbosa (pers) Fr," Journal of Pharmacy Research, vol. 4, no. 11, article 39, 2011.

[25] G. Zengin, A. Karanfil, M. C. Uren et al., "Phenolic content, antioxidant and enzyme inhibitory capacity of two: Trametes species," RSC Advances, vol. 6, no. 77, pp. 73351-73357, 2016.

[26] S. Tomasi, F. Lohezic-Le Devehat, P. Sauleau, C. Bézivin, and J. Boustie, "Cytotoxic activity of methanol extracts from Basidiomycete mushrooms on murine cancer cell lines," Die Pharmazie, vol. 59, no. 4, pp. 290-293, 2004.

[27] M. K. Mbayo, E. M. Kalonda, P. T. Tshisand, O. Tatchoua, S. Kamulete, and K. Glauber, "Chemical Screening of some mushrooms of Katanga (DRC) and their biological activities evaluation," vol. 10, pp. 435-449, 2015.

[28] M. Kabuyi, P. Kapepula, J. Kabengele, B. Moni, G. Makengo, and P. Mungitshi, "Selenium content and antioxidant potential of some edible wild mushrooms from Bandundu Area, DR Congo," NaturalResources, vol. 8, no. 2, pp. 103-113, 2017.

[29] P. M. Kidd, "The use of mushroom glucans and proteoglycans in cancer treatment," Alternative Medicine Review, vol. 5, no. 1, pp. 4-27, 2000.

[30] A. M. Tripathi and B. N. Tiwary, "Biochemical constituents of a wild strain of Schizophyllum commune isolated from Achanakmar-Amarkantak Biosphere Reserve (ABR), India," World Journal of Microbiology and Biotechnology, vol. 29, no. 8, pp. 1431-1442, 2013.

[31] R. M. R. Dulay, J. J. A. Vicente, A. G. Dela Cruz et al., "Antioxidant activity and total phenolic content of Volvariella volvacea and Schizophyllum commune mycelia cultured in indigenous liquid media," Mycosphere, vol. 7, no. 2, pp. 131-138, 2016.
[32] S. P. Wasser, "Medicinal mushrooms as a source of antitumor and immunomodulating polysaccharides," Applied Microbiology and Biotechnology, vol. 60, no. 3, pp. 258-274, 2002.

[33] A. Demirhan, O. F. Yesil, A. Yildiz, and K. A. Gul, "A research on antimicrobial activity of some macro fungi species," Science and Engineering Journal of Firat University, vol. 19, no. 4, pp. 425433, 2007.

[34] S. C. Punitha and M. Rajasekaran, "Free radical scavenging activity of fruiting body extracts of an edible mushroom, Volvariella volvacea (Bull.ex Fr.) Singer: an in vitro," Journal of Biomedical and Pharmaceutical Sciences, vol. 4, no. 30, pp. 6-11, 2014.

[35] K. Acharya, "Leishmanicidal and anti-candidal activity of constituents of Indian edible mushroom Astraeus hygrometricus," Chemical Biodiversivity, vol. 9, no. 8, pp. 1517-1524, 2012.

[36] S. Maiti, S. K. Bhutia, S. K. Mallick, A. Kumar, N. Khadgi, and T. K. Maiti, "Antiproliferative and immunostimulatory protein fraction from edible mushrooms," Environmental Toxicology and Pharmacology, vol. 26, no. 2, pp. 187-191, 2008.

[37] Y. Wu, H. Wang, and T. B. Ng, "Purification and characterization of a lectin with antiproliferative activity toward cancer cells from the dried fruit bodies of Lactarius flavidulus," Carbohydrate Research, vol. 346, no. 16, pp. 2576-2581, 2011.

[38] P. V. Jeurink, C. L. Noguera, H. F. J. Savelkoul, and H. J. Wichers, "Immunomodulatory capacity of fungal proteins on the cytokine production of human peripheral blood mononuclear cells," International Immunopharmacology, vol. 8, no. 8, pp. 1124-1133, 2008.

[39] W. A. S. W. Perera, D. T. U. Abeytunga, and R. L. C, "Antimicrobial activities of Volvariella volvacea," Jounal of Natural Science Found in Sri Lanka, vol. 29, no. 1\&2, pp. 61-68, 2001.

[40] R. F. da Silva, A. C. D. A. Barros, M. Pletsch, A. C. Cavalcante Malta Argolo, and B. S. de Araujo, "Study on the scavenging and anti-Staphylococcus aureus activities of the extracts, fractions and subfractions of two Volvariella volvacea strains," World Journal of Microbiology and Biotechnology, vol. 26, no. 10, pp. 1761-1767, 2010.

[41] S. Giri, G. Biswas, P. Pradhan, S. C. Mandal, and K. Acharya, "Antimicrobial activities of basidiocarps of wild edible mushrooms of West Bengal, India," International Journal of PharmTech Research, vol. 4, no. 4, pp. 1554-1560, 2012.

[42] S. M. K. Ayodele and M. E. Idoko, "Antimicrobial activities of four wild edible mushrooms in Nigeria," Internatinaol Journl of Science and Nature, vol. 2, no. 1, pp. 55-58, 2011.

[43] C. K. Kokate, A. P. Purohit, and S. B. Gokhale, Pharmacognosy, Nirali Prakashan, Pune, India, 32nd edition, 2001.

[44] W. C. Evans, Trease and Evans' Pharmacognosy, Elsevier Health Sciences, Amsterdam, Netherlands, 2009.

[45] M. S. Marica, S. B. A. JIvona, and M. Ana, "Optimization of chromatographic conditions in thin layer chromatography of flavonoids and phenolic acids," Croatica Chemica Acta, vol. 77, no. 1-2, pp. 361-366, 2010.

[46] C. Agyare, G. A. Koffuor, V. E. Boamah, F. Adu, K. B. Mensah, and L. Adu-Amoah, "Antimicrobial and anti-inflammatory activities of Pterygota macrocarpa and Cola gigantea (Sterculiaceae)," Evidence-Based Complementary and Alternative Medicine, vol. 2012, Article ID 902394, 9 pages, 2012.

[47] P. Cos, A. J. Vlietinck, D. V. Berghe, and L. Maes, "Anti-infective potential of natural products: how to develop a stronger in vitro proof-of-concept," Journal of Ethnopharmacology, vol. 106, no. 3, pp. 290-302, 2006. 
[48] B. T. Tsuji, J. C. Yang, A. Forrest, P. A. Kelchlin, and P. F. Smith, "In vitro pharmacodynamics of novel rifamycin ABI0043 against Staphylococcus aureus," Journal of Antimicrobial Chemotherapy, vol. 62, no. 1, pp. 156-160, 2008.

[49] M. Obodai, J. Cleland-Okine, and K. A. Vowotor, "Comparative study on the growth and yield of Pleurotus ostreatus mushroom on different lignocellulosic by-products," Journal of Industrial Microbiology and Biotechnology, vol. 30, no. 3, pp. 146-149, 2003.

[50] J. W. Kimenju, G. O. M. Odero, E. W. Mutitu, P. M. Wachira, R. D. Narla, and W. M. Muiru, "Suitability of locally available substrates for oyster mushroom (Pleurotus ostreatus) cultivation in Kenya," Asian Journal of Plant Sciences, vol. 8, no. 7, pp. 510514,2009 .

[51] S. Wang, L. Bao, F. Zhao et al., "Isolation, identification, and bioactivity of monoterpenoids and sesquiterpenoids from the mycelia of edible mushroom pleurotus cornucopiae," Journal of Agricultural and Food Chemistry, vol. 61, no. 21, pp. 5122-5129, 2013.

[52] M. K. Kim, R. K. Math, K. M. Cho et al., "Effect of Pseudomonas sp. P7014 on the growth of edible mushroom Pleurotus eryngii in bottle culture for commercial production," Bioresource Technology, vol. 99, no. 8, pp. 3306-3308, 2008.

[53] Y. Prasad and W. E. G. Wesely, "Antibacterial activity of the bio-multidrug (Ganoderma lucidum) on Multidrug resistant Staphylococcus aureus (MRSA)," Journal of Advanced Biotechnology, vol. 10, p. 16, 2008.

[54] M. T. G. Silva, S. M. Simas, T. G. Batista, P. Cardarelli, and T. C. B. Tomassini, "Studies on antimicrobial activity, in vitro, of Physalis angulata L. (Solanaceae) fraction and physalin B bringing out the importance of assay determination," Memórias do Instituto Oswaldo Cruz, vol. 100, no. 7, pp. 779-782, 2005.

[55] O. Keleş, T. Bakirel, S. Şener, G. Baktir, G. Daǧoǧlu, and O. Özkan, "Pharmacokinetics and tissue levels of tilmicosin in fowls," Turkish Journal of Veterinary \& Animal Sciences, vol. 25, no. 4, pp. 629-634, 2001.

[56] K. Dornberger, W. Ihn, W. Schade, D. Tresselt, A. Zureck, and L. Radics, "Antibiotics from basidiomycetes evidence for the occurrence of the 4-hydroxybenzenediazonium ion in the extracts of agaricus xanthodermus genevier (agaricales)," Tetrahedron Letters, vol. 27, no. 5, pp. 559-560, 1986.

[57] V. E. C. Ooi and F. A. Liu, "A review of pharmacological activities of mushroom polysaccharides," International Journal of Medicinal Mushrooms, vol. 1, no. 3, pp. 195-206, 1991.

[58] H. Matsuyama, R. E. P. Mangindaan, and T. Yano, "Protective effect of schizophyllan and scleroglucan against Streptococcus $s p$. infection in yellowtail (Seriola quinqueradiata)," Aquaculture, vol. 102, no. 3-4, pp. 197-203, 1992.

[59] I. Suay, F. Arenal, F. J. Asensio, A. Basilio, M. A. Cabello, and M. T. Diez, "Screening of Basidiomycetes for antimicrobial activities," Anton Van Leeuwen, vol. 78, no. 3, pp. 3-8, 2000.

[60] C. Papadopoulou, K. Soulti, and I. G. Roussis, "Potential antimicrobial activity of red and white wine phenolic extracts against strains of staphylococcus aureus, escherichia coli and Candida albicans," ood Technology and Biotechnology, vol. 43, no. 1, pp. 41-46, 2005.

[61] G. Nagaraj, M. V. Uma, M. S. Shivayogi, and H. Balaram, "Antimalarial activities of peptide antibiotics isolated from fungi," Antimicrobial Agents and Chemotherapy, vol. 45, no. 1, pp. 145149, 2001.

[62] F. Kalyoncu, M. Oskay, H. Sağlam, T. F. Erdoğan, and A. U. Tamer, "Antimicrobial and antioxidant activities of mycelia of
10 wild mushroom species," Journal of Medicinal Food, vol. 13, no. 2, pp. 415-419, 2010.

[63] T. R. Keepers, M. Gomez, C. Celeri, W. W. Nichols, and K. M. Krause, "Bactericidal activity, absence of serum effect, and timekill kinetics of ceftazidime-avibactam against $\beta$-lactamaseproducing enterobacteriaceae and Pseudomonas aeruginosa," Antimicrobial Agents and Chemotherapy, vol. 58, no. 9, pp. 52975305, 2014.

[64] G. A. Pankey and L. D. Sabath, "Clinical relevance of bacteriostatic versus bactericidal mechanisms of action in the treatment of gram-positive bacterial infections," Clinical Infectious Diseases, vol. 38, no. 6, pp. 864-870, 2004.

[65] Z. Aumeeruddy-Elalfi, A. Gurib-Fakim, and M. F. Mahomoodally, "Chemical composition, antimicrobial and antibiotic potentiating activity of essential oils from 10 tropical medicinal plants from Mauritius," Journal of Herbal Medicine, vol. 6, no. 2, pp. 88-95, 2016.

[66] Y. D. Boakye, C. Agyare, and H. Andreas, "Anti-infective properties and time-kill kinetics of Phyllanthus muellerianus and its major constituent, geraniin," Medicinal Chemistry, vol. 6, no. 2, pp. 95-104, 2016.

[67] S. Tinrat, "Antimicrobial activities and synergistic effects of the combination of some edible mushroom extracts with antibiotics against pathogenic strains," International Journal of Pharmaceutical Sciences Review and Research, vol. 35, no. 2, pp. 253-262, 2015. 


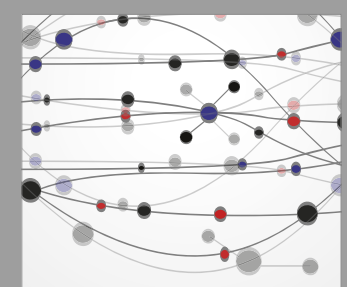

The Scientific World Journal
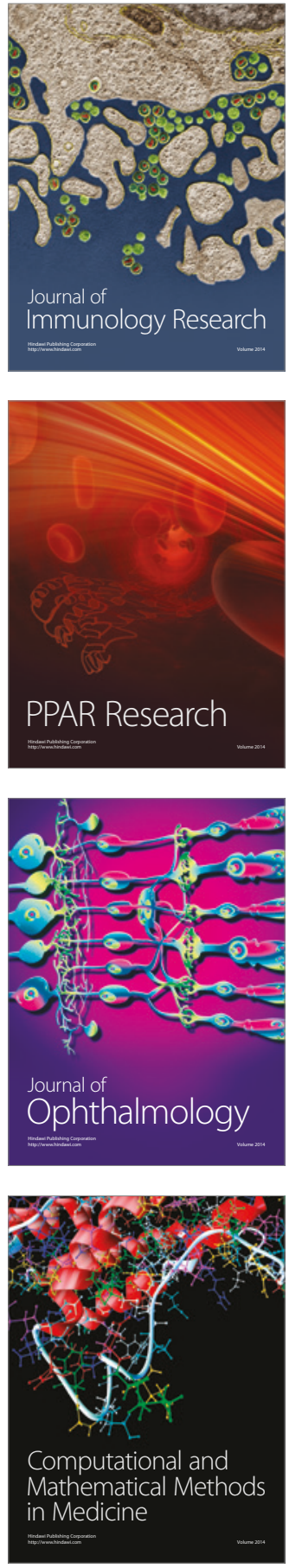

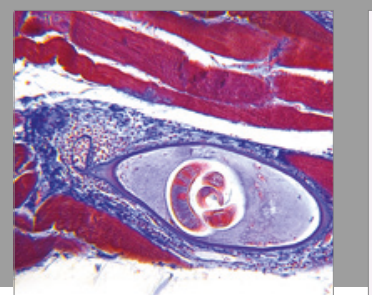

Gastroenterology Research and Practice
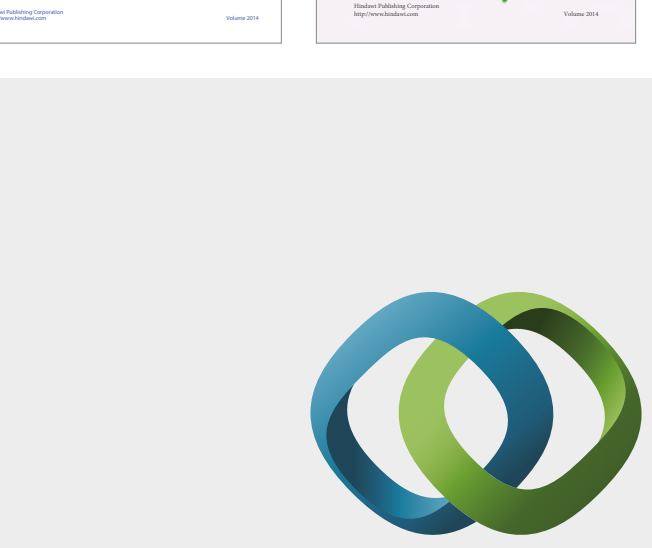

\section{Hindawi}

Submit your manuscripts at

https://www.hindawi.com
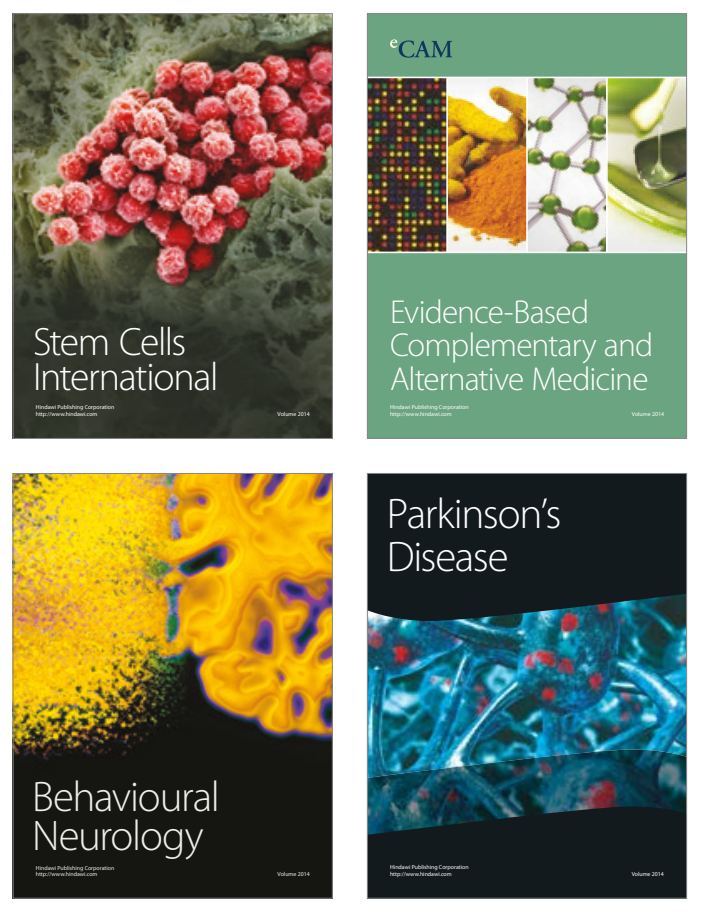
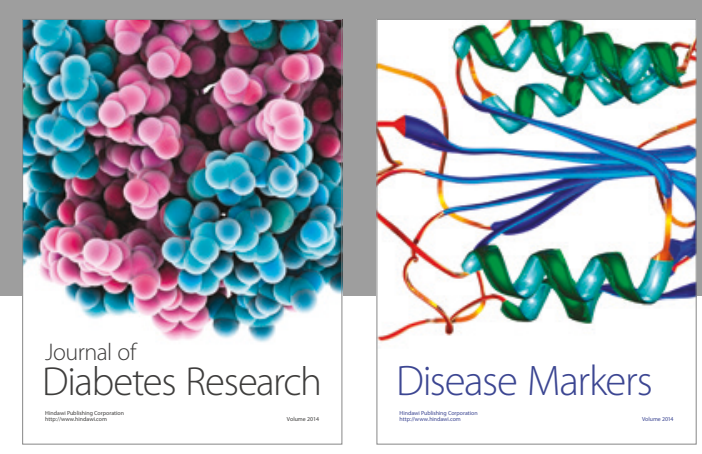

Disease Markers
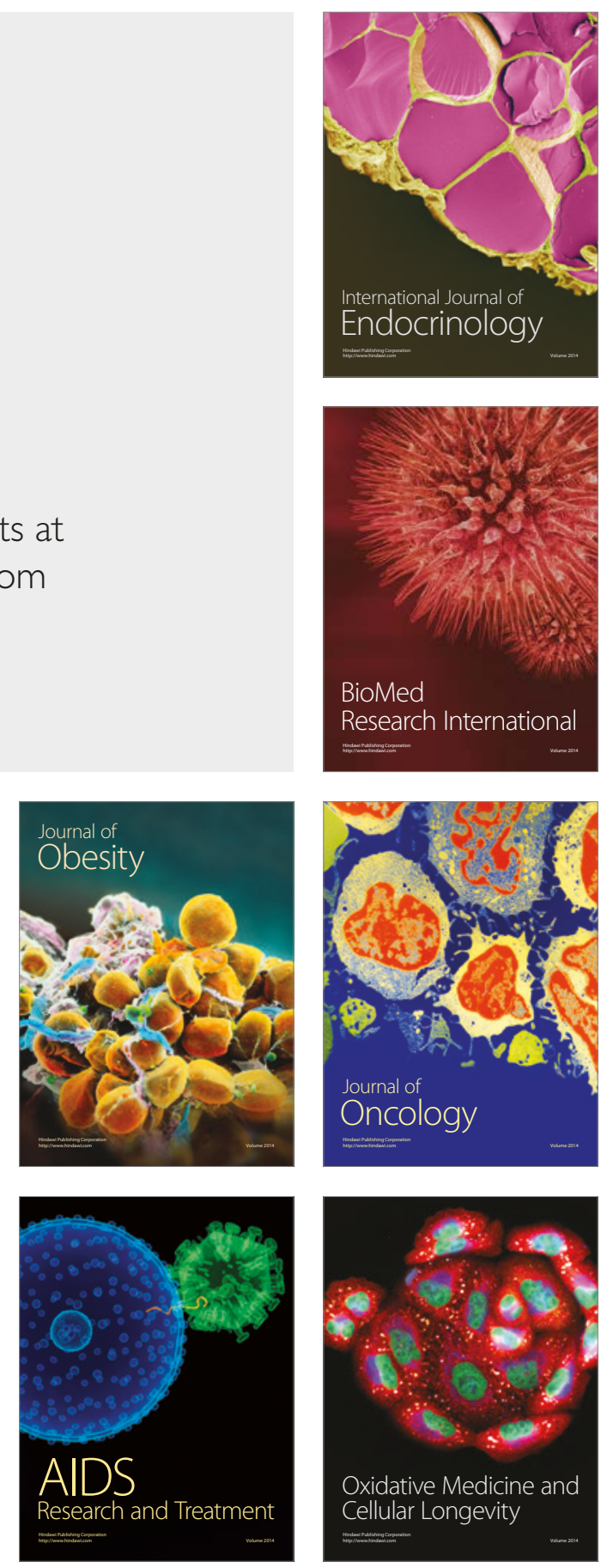